\title{
Dissolved Organic and Inorganic Carbon Flow Paths in an Amazonian Transitional Forest
}

\author{
Vania Neu ${ }^{1 *}$, Nicholas D. Ward ${ }^{2 \star}$, Alex V. Krusche ${ }^{3}$ and Christopher Neill ${ }^{4}$ \\ ${ }^{1}$ Instituto Socio Ambiental e dos Recursos Hidricos, Universidade Federal Rural da Amazônia, Belem, Brazil, ${ }^{2}$ Department of \\ Geological Sciences, University of Florida, Gainesville, FL, USA, ${ }^{3}$ Centro de Energia Nuclear na Agricultura, Universidade de \\ São Paulo, Piracicaba, Brazil, ${ }^{4}$ The Ecosystems Center, Marine Biological Laboratory, Woods Hole, MA, USA
}

As a raindrop falls from the atmosphere, over vegetation and forest canopies, and enters soils and streams it experiences a dynamic exchange of carbon constituents with the surrounding environment. Understanding the magnitude and dynamics of carbon export in above and below ground flow paths is critical for constraining the influence of terrestrial and aquatic ecosystems on global carbon cycling. Here we examine the concentration and flux of dissolved organic and inorganic carbon (DOC and DIC) in rainfall, throughfall, stemflow, overland flow, soil solution, groundwater, and stream water in an Amazonian transitional forest located near the arc of deforestation. Rainfall was enriched in DOC by interactions with atmospheric particles derived from both biogenic and anthropogenic emissions, resulting in a flux of $82.3 \mathrm{~kg} \mathrm{C} \mathrm{ha}^{-1} \mathrm{yr}^{-1}$, which was the largest flux from each respective flow path. Forest throughfall, stemflow, and direct overland flow mobilized DOC from products of terrestrial primary production and decomposition. Net throughfall represented the second largest DOC flux $\left(68.4 \mathrm{~kg} \mathrm{C} \mathrm{ha}^{-1} \mathrm{yr}^{-1}\right)$, whereas stemflow and overland flow only had a flux of 1.5 and $3.9 \mathrm{~kg} \mathrm{C} \mathrm{ha}^{-1} \mathrm{yr}^{-1}$, respectively. Much of the DOC in above ground flow paths was removed from solution as the rain percolated through soil layers due to both biological decomposition and sorption/desorption to mineral surfaces, resulting in low concentrations in stream and groundwater $\left(2.6 \pm 2.4 \mathrm{mg} \mathrm{L}^{-1}\right.$ and $1.45 \pm$ $0.3 \mathrm{mg} \mathrm{L}^{-1}$, respectively) relative to throughfall $\left(43.9 \pm 5.2 \mathrm{mg} \mathrm{L}^{-1}\right)$ and stemflow (30.6 $\pm 2.7 \mathrm{mg} \mathrm{L}^{-1}$ ). The flux of DIC in each respective flow path was generally lower than for DOC, and likely driven by atmospheric gas exchange and inputs from respiration and decomposition. DOC concentrations in above ground flow paths were highest during the first rainfall after a dry period, whereas DIC concentrations generally increased throughout the rainy season as soil moisture increased.

Keywords: tropical forest, carbon, organic, inorganic, flow path, flux, rainfall, terrestrial

\section{INTRODUCTION}

Carbon derived from the terrestrial biosphere is mobilized by rainfall into soils, streams, and groundwater through numerous pathways. Before hitting a forest canopy or uncovered ground, a raindrop interacts with organic carbon (OC) rich particles in the atmosphere (Artaxo et al., 1988; Talbot et al., 1990). This interaction results in the enhancement of dissolved organic carbon (DOC) concentrations in precipitation (Andreae et al., 1990; Artaxo et al., 2005; Waterloo et al., 2006; Germer et al., 2007). Precipitation drives a flux of OC from the atmosphere to the landscape 
via dry deposition, atmosphere washing, and incorporation of aerosols in rain drop condensation nuclei (Artaxo et al., 2005). Rainfall receives additional inputs of carbon as it travels through forest canopies (e.g., throughfall) and down trunks and stems (e.g., stem flow); litterfall also provides a significant source of fresh OC as rainfall percolates through subsurface soil layers into streams and groundwater (Qualls et al., 2002).

Much of the OC flux described above is removed from the water while traveling through soil layers as a result of both sorptive and biodegradative processes, leaving stream and groundwater with low DOC concentrations relative to above ground flow paths (Qualls and Haines, 1992; Schmidt et al., 2011). Remineralization rates of OC in soils are high and may be enhanced by global climate change (Feng et al., 2008). OC derived from terrestrial primary production and dissolved inorganic carbon (DIC) derived from root and soil respiration is mobilized from soil layers into streams and groundwater reservoirs. Rivers and streams are typically supersaturated with respect to $\mathrm{CO}_{2}$ as a result of direct inputs of DIC and remineralization of terrestrially-derived OC (Raymond et al., 1997; Richey et al., 2002; Mayorga et al., 2005; Ward et al., 2013). Inland waters emit $2.1 \mathrm{Pg} \mathrm{C} \mathrm{yr}^{-1}$, globally, of which $70 \%$ comes from the tropics and 25\% from the Amazon River, alone (Raymond et al., 2013).

Carbon fluxes to both the atmosphere and ocean are generally higher in tropical regions relative to temperate and high-latitude counterparts (Aufdenkampe et al., 2011). Covering a region of over 6 million $\mathrm{km}^{2}$, the highly productive Amazon basin plays a significant role in the global carbon cycle. The Amazon rainforest is responsible for roughly $10 \%$ of global terrestrial primary production and the Amazon River represents roughly 20\% of the world's freshwater flux (Field et al., 1998; Malhi et al., 2008). The extensive basin contains regions with relatively little human perturbation, and regions highly impacted by deforestation and burning. The Amazon rainforest naturally produces large amounts of OC-rich aerosols through biogenic emissions that are eventually entrained in rainfall (Talbot et al., 1990). The size and morphology of these particles is highly diverse with origins from plant sources such as pollen grains, fungi, algae, and plant fragments (Artaxo et al., 1988).

Deforestation and biomass burning, along with other anthropogenic emissions, can also add aerosols to the atmosphere. For example, aerosol concentrations in Amazonian regions situated in the arc of deforestation have increased during recent years as a result in enhanced anthropogenic activities (Artaxo et al., 2005). Aerosol concentrations were generally highest during the dry season in these regions due to large amounts of grass and forest burning in addition to dust derived from agricultural and exposed soil sites (Artaxo et al., 2005). The majority of the carbon from these aerosols is transported from the atmosphere to the land at the beginning of the wet season, with rainfall DOC concentrations decreasing with additional precipitation (Filoso et al., 1999; Johnson et al., 2006a; Germer et al., 2007).

Throughfall is an important component of forest carbon cycling. The primary carbon input pathway is canopy washing. In the Amazon rainforest, throughfall has been observed to represent roughly $75-90 \%$ of total rainfall (Lloyd and Marques,
1988; Filoso et al., 1999; Ferreira et al., 2005). Stemflow generally has even higher DOC concentrations than rainfall and throughflow, but the total flux is low since stemflow only represents $2-8 \%$ of total rainfall in the Amazon (Jordan, 1978; Lloyd and Marques, 1988). Overland flow occurs either when rainfall occurs more rapidly than soil infiltration (Horton, 1933) or when soils are completely saturated (Linsley et al., 1975). Overland flow generally has greater DOC concentrations than throughfall and is transported rapidly. However, as with stemflow, overland flow is generally low compared to other flow paths in preserved forests, resulting in a relatively small overland DOC flux (Johnson et al., 2006a; Waterloo et al., 2006). In surface soils and organic matter layers DOC concentrations are generally high as a result of initial enrichment of throughfall and leaching of decomposing organic matter; soil solution concentrations typically decrease with soil depth as a result of mineral sorption and OC remineralization (McClain et al., 1997; Liu and Sheu, 2003). The removal of OC in soils leaves stream and ground water with low DOC concentrations relative to the preceding flow paths (Qualls et al., 2002; Liu and Sheu, 2003; Waterloo et al., 2006; Johnson et al., 2006a).

The objective of the present study is to determine the concentration and flux of DOC and DIC in each respective flow path: rainfall, throughfall, stemflow, overlandflow, soil solution, groundwater, and streamwater in an Amazonian forest. Water samples were collected monthly between February 2007 and January 2008 using a series of collectors designed for each flow path. The forest studied here is transitional between tropical rainforest and savanna, and is situated in the arc of deforestation in Brazil (Figure 1). In recent decades this region has lost large amounts of forested area due to deforestation and land use change.

\section{METHODS \\ Study Site}

The study was conducted at Tanguro Ranch in the southern Amazonian state of Mato Grosso, Brazil. Tanguro Ranch $\left(12^{\circ}\right.$ $\left.53^{\prime} \mathrm{S}, 52^{\circ} 21^{\prime} \mathrm{W}\right)$ lies southeast of the Xingu Indigenous Park in the municipalities of Canarana and Querência at an elevation of $\sim 350 \mathrm{~m}$ above sea level in the upper region of the Xingu drainage basin between the Tanguro and Darro Rivers (Figure 1). Topography of the region consists of wide plains and gentle slopes to the waterways in a landscape with little other pronounced relief. It lies on a portion of the Brazilian Shield underlain by Precambrian Gneisses of the Xingu Complex. Soils consist of Oxisols (Haplustox/Latossolo vermelho-amarelo distrófico) on the broad, flat uplands away from the rivers. These soils have a water table depth of 12-15 $\mathrm{m}$ and no impeding layers. Throughout the year the water table depth varies by $0.27 \mathrm{~m}$ in the lowland and $1.07 \mathrm{~m}$ in the plateau. Wetter, and occasionally inundated, soils (Gleissols) of similar origin are found along the river margins (Projeto Radambrasil, 1981).

The pre-agricultural vegetation of the Tanguro region is evergreen tropical forest (Walter, 1979; Ivanauskas et al., 2004) typical of the transition from Cerrado to the central Amazon rainforest. The vegetation of this transition zone has lower species 

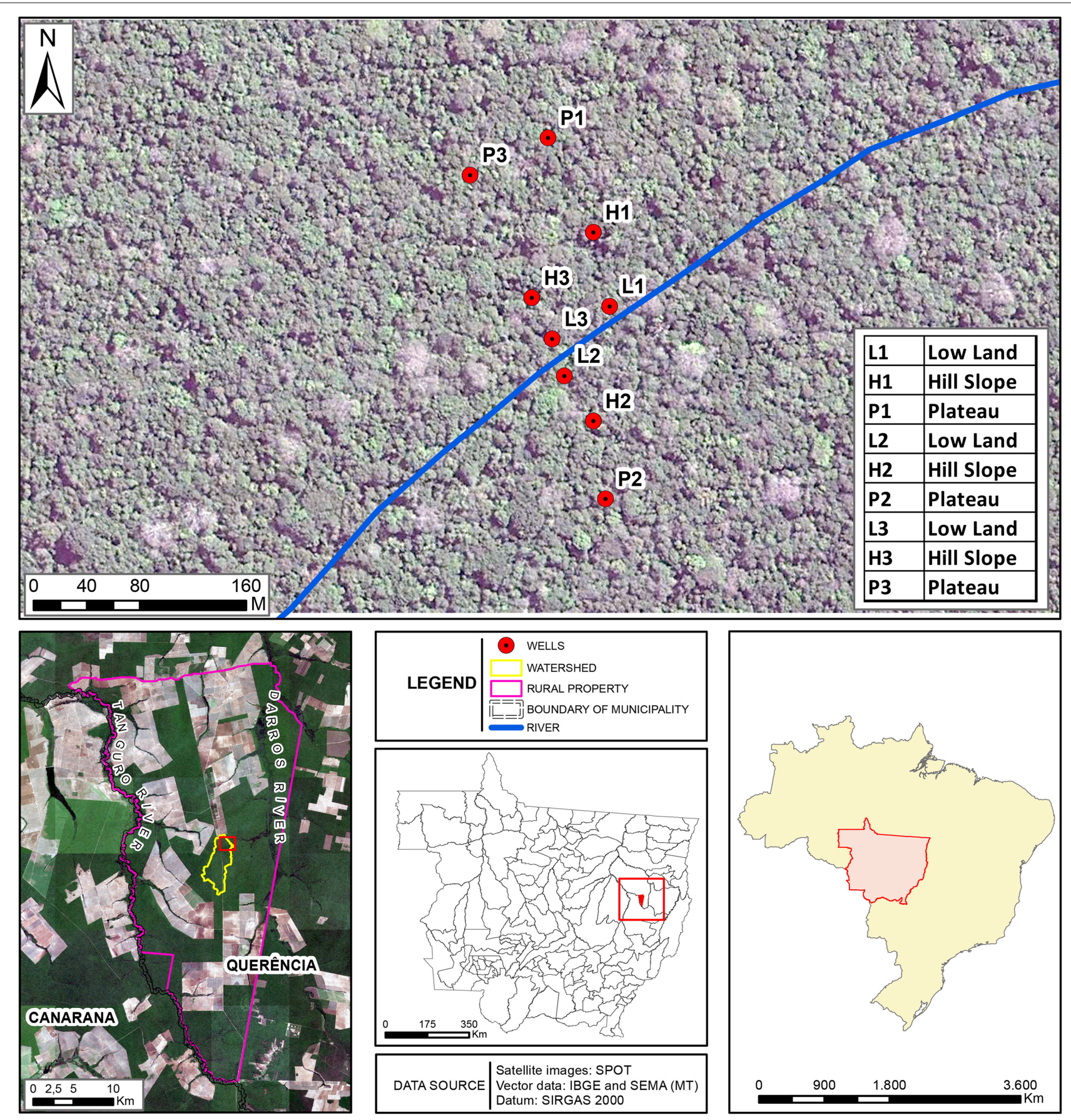

FIGURE 1 | Study site. Samples were collected in the Tanguro Ranch watershed in the Xingu drainage basin between the Tanguro and Darro Rivers.

diversity, smaller trees, and lower canopy heights compared to many previously studied Amazonian forests (Ivanauskas et al., 2004). The climate at Tanguro is humid tropical. Average annual precipitation from 1987 to 2007 was $1905 \pm 271 \mathrm{~mm}$ and is strongly seasonal, with $<5 \%$ of total annual precipitation falling between May and September (Vianello and Alves, 2002). June, July and August are the three driest months with typically less than $10 \mathrm{~mm}$ rain per month. Mean annual temperature is $25^{\circ} \mathrm{C}$. During this study, hourly rainfall and rain intensity were recorded at a weather station $27 \mathrm{~km}$ south of the study boundaries. Daily rainfall was also measured in two collectors 2 and $5 \mathrm{~km}$ from the study site.

The completely forested watershed studied here covers an area of $13.20 \mathrm{~km}^{2}$. The watershed is drained by a perennial first-order stream. Broad, flat plateaus typical of the region dominate the majority of the watershed's topography, which transitions into 
a distinct shoulder hillslope zone and narrower/flatter lowland, near-stream zone. The watershed boundaries were delineated from Shuttle Mission Radar Topography data and validated with field measurements with a high-precision differential GPS (Figure 1). This watershed was divided into three parcels and nine sub-parcels. Each parcel lies along a topographic gradient, with three sub-parcels (lowland, hillside and plateau).

\section{Sample Collection}

Water samples were collected to assess the organic and inorganic carbon content of rainfall, throughfall, stemflow, overland flow, soil solution, groundwater, and streamwater between February 2007 and January 2008. Soil solution samples were collected with tension lysimeters on a monthly basis, however, soils were too dry to extract water from June to November. The lysimeter was rinsed with distilled water before use, and after installation the first collection was discarded. Tension lysimeters were installed at depths of $10,50,100$, and $200 \mathrm{~cm}$, in each sub-parcel (36 collectors total). Soil solution was collected from the lysimeters after setting the vacuum for $24 \mathrm{~h}$ at 0.6 bars. Samples were stored in acid-washed $250 \mathrm{~mL}$ glass bottles and sealed with silicone stoppers.

Overland flow samples were collected using 27 collectors installed along the nine sub-parcels (three collectors in each). The collectors consisted of a PVC pipe $(200 \mathrm{~cm}$ wide with 15 $\mathrm{cm}$ diameter) that was closed in the two extremities with PVC caps. In one extremity the cap had a small opening connected to a reservoir (10 L capacity) to store the sample. The collectors have a transversal opening $(3 \times 190 \mathrm{~cm})$, that allows the collection of water originating from overland flow. The collectors were inserted horizontally into the soil such that the opening of the collector was near the soil surface. Below the soil surface (3 $\mathrm{cm})$, a small horizontal cut in the soil parallel to the collector was made in order to install a polystyrene plate $(10 \times 190$ $\mathrm{cm})$. This plate was fixed into the collector, and into the soil, making a connection between the soil and collector to permit the overland flow to enter the collector. The captivating area of each collector was delimited to $6 \mathrm{~m}^{2}$ plots with wooden boards inserted into the soil. This was done to prevent the collection of water from areas uphill and lateral of each plot. The overland flow collectors were prepared for collection every 15 days by connecting the collector to the reservoir. Samples were collected from the reservoirs 1 day after each sampled rain event. The collectors were set to bypass the reservoir in between samplings, automatically discarding any water. During each sampling the volume of water collected in each collector was measured using a digital dynamometer (Insthutherm, Model DD-200).

Throughfall samples were collected biweekly with 27 collectors installed along the nine sub-parcels (three collectors in each). Collectors were dispersed randomly to avoid bias due to canopy density. The collector is a suspended channel made with a PVC pipe $(150 \mathrm{~cm}$ wide with $15 \mathrm{~cm}$ diameter) that is closed on one end with PVC caps. The other end had a funnel connected to a reservoir ( $20 \mathrm{~L}$ capacity) to store the sample. The funnel was covered with plastic so as not to increase the capture area of water. The channel had a transversal opening $(7 \times 140$ $\mathrm{cm}$ ) in the direction of the tree's canopy. The captivating area of each collector was $980 \mathrm{~cm}^{2}$. The collector was suspended $1 \mathrm{~m}$ above the soil surface. Rainfall was collected in the same type of collectors installed in triplicate in an open area.

Groundwater was collected every 15 days from nine wells in the watershed during the rainy season and monthly during the dry season. Screened groundwater wells made of $10 \mathrm{~cm}$ diameter PVC pipes were installed by hand at different depths depending on their position along the topographic gradient. Transversal cuts were made in the sides of the pipe $1.5 \mathrm{~m}$ from the bottom so that groundwater could flow in and out of the well. Lowland wells were between 1.69 and $2.14 \mathrm{~m}$ deep, hill slope wells were 4.84 to $6.25 \mathrm{~m}$ deep, and plateau wells were 7.07 to $9.65 \mathrm{~m}$ deep. Groundwater was collected with a manual collector, made with a PVC pipe ( $82 \mathrm{~cm}$ wide and $5 \mathrm{~cm}$ diameter) and a movable glass bottom. Roughly $3 \mathrm{~L}$ of water was removed prior to sample collection to insure that water that had most recently arrived at the well was collected.

Stemflow was collected along the catchment in three randomly located $10 \times 10 \mathrm{~m}$ plots along the topographic gradient. In each plot collectors (48 total) were installed on trees with a diameter $\geq 5 \mathrm{~cm}$. Polystyrene plates $(2.5 \mathrm{~cm}$ wide) were fitted around the tree trunks in a downward spiral connected to a $20 \mathrm{~L}$ reservoir, starting $1.5 \mathrm{~m}$ above the forest floor, similar to the collectors described by Likens and Eaton (1970). To assess possible contamination from the collectors, plastic components of the collectors were immersed in deionized water for 3 days and the DOC was measured. There was no detectable organic contamination from the collectors.

\section{Sample Analysis}

The $\mathrm{pH}$ and conductivity of water samples was determined with Orion (model 250A) and Amber Science (model 2052) probes, respectively (Supplementary Tables 1-7). For DOC samples $30 \mathrm{~mL}$ of water was filtered through $0.7 \mu \mathrm{m}$ pore size combusted GFF filters (Whatman) into combusted glass vials and preserved in the field with $75 \mathrm{~mL}$ of $6 \mathrm{~N} \mathrm{HCl}$. DOC concentrations were measured on a Shimadzu total carbon analyzer (Model TOC-VCPH). For DIC samples $60 \mathrm{ml}$ of water was filtered through $0.47 \mu \mathrm{m}$ cellulose acetate membrane filters (Millipore) into acid-washed $60 \mathrm{~mL}$ HDPE bottles with no headspace to avoid degassing and preserved with thymol (100 $\mathrm{mg} / 1000 \mathrm{ml}$ of solution). DIC samples were analyzed for total organic carbon before acidification on a Shimadzu total carbon analyzer (Model TOC-VCPH). DIC samples were then acidified using $6 \mathrm{~N} \mathrm{HCl}$ and sparged to remove gas and reanalyzed for total organic carbon. DIC was calculated as the difference between non-acidified and acidified/sparged samples. This method may slightly underestimate DIC concentrations due to degassing during filtration. However, this method has been compared to DIC calculations from $\mathrm{CO}_{2}$ values and the variation is typically minimal, whereas alkalinity titrations result in high amounts of error in DOC-rich acidic waters (Neu et al., 2011). Samples were stored in the dark at room temperature for roughly 1 week prior to analysis. Samples could not be kept cold since there was no electricity available at the field site. 


\section{Rainfall and Stream Discharge}

Hourly rainfall and rain intensity was recorded at the Tanguro Ranch weather station $27 \mathrm{~km}$ south of the sampling location. Daily rainfall was also recorded in two collectors roughly 2 $\mathrm{km}$ from the watershed sampling point. Stream stage was recorded every $15 \mathrm{~min}$ from May to August 2007 with an ISCO 6200 automatic sampler equipped with a pressure transducer module. From August 2007 to August 2008 stream stage was recorded hourly with an Onset water level logger. A rating curve was developed by periodic measurements of stream discharge with a Global Water FP-101 current meter across a range of stream flows. Hourly stream flows for January to May 2007 were estimated from daily rainfall and rainfall-stream flow relationships from the same location derived from the 16-month stream flow record that began in May.

\section{Flux Estimates}

We estimated total annual DOC and DIC fluxes in throughfall based on our record of rainfall and intensity from Tanguro Ranch, measured DOC and DIC concentrations from the sampled rain events, extrapolated DOC and DIC concentrations for non-sampled events, and an estimate of canopy interception for a tropical forest. Precipitation during sampled events $(n=10)$ ranged from 0 to $115 \mathrm{~mm}$ and unsampled events $(n=51)$ ranged from 0 to $75 \mathrm{~mm}$. We assumed that throughfall was on average $85 \%$ of precipitation (Lloyd and Marques, 1988; Filoso et al., 1999; Ferreira et al., 2005) to calculate total througfall volume duirng unsampled events. Average DOC and DIC concentrations from sampled events were used to estimate concentrations during unsampled events with similar amounts of precipitiation.

We estimated water volumes for stemflow during unsampled events from relationships of measured volumes (in $\mathrm{mm}$ ) between throughfall and stemflow (Figure 2A):

$$
\mathrm{SF}=6.35 \times 10^{-5}(\mathrm{TF})^{2}+0.0063(\mathrm{TF})-0.0252 ; \mathrm{r}^{2}=0.86
$$

where SF is stemflow and TF is throughfall. Likewise, overland flow (OF) was calculated based on the following relationship between overland flow and throughlow (Figure 2B):

$$
\mathrm{OF}=0.0116(\mathrm{TF})+0.0383 ; \mathrm{r}^{2}=0.84
$$

We then used these calculated volumes and mothly mean DOC concentrations in stemflow and overland flow from the nearest sampled event to calculate DOC fluxes for each unsampled event. We then summed DOC fluxes for all sampled and unsampled events to obtain an annual flux.

\section{Statistical Analysis}

The results were submitted to analysis of variance and subsequently Tukey median comparison test for the variables with statistically significant differences, using the GLM (General Linear Models) procedure, using SAS 9.1 software (Statistical Analysis System). The tests were considered significantly different for $p<0.05$.
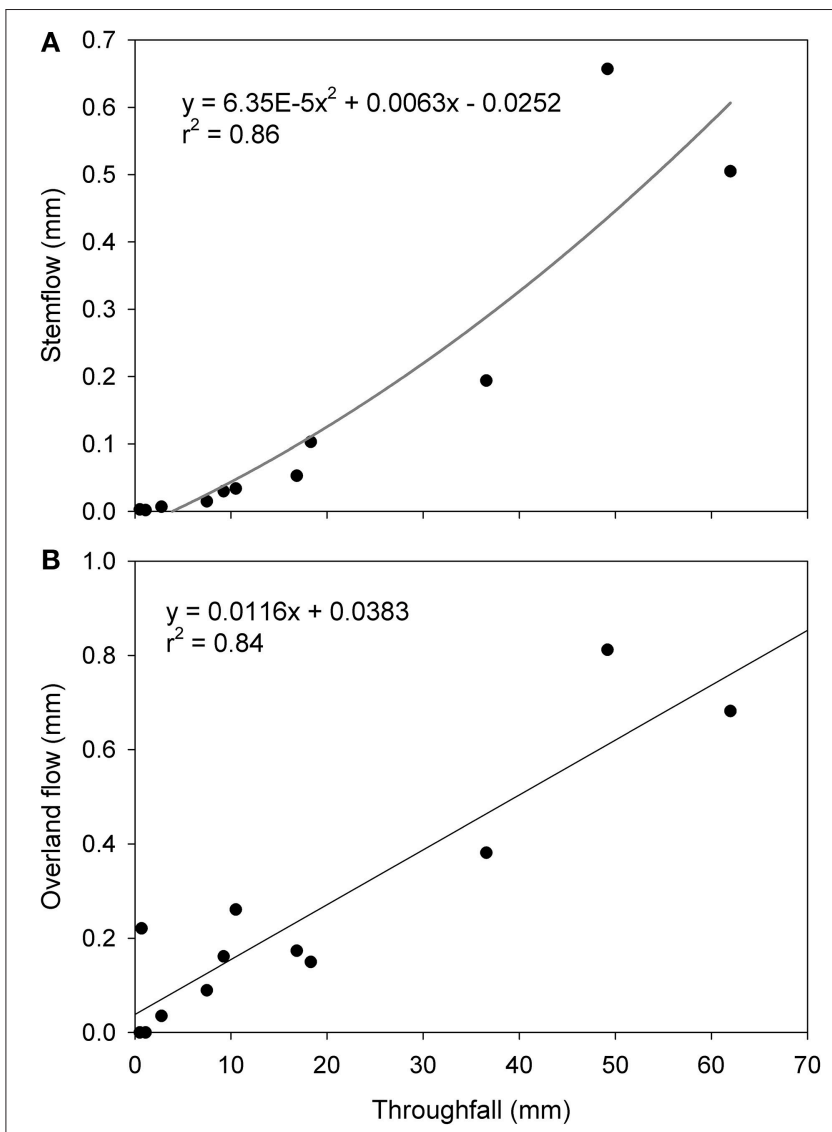

FIGURE 2 | Correlation between throughfall, stemflow, and overland flow. The correlation between throughfall and stemflow (A) and throughfall and overland flow (B) was used to calculate stemflow and overland flow for unsampled events.

\section{RESULTS}

\section{Precipitation and Stream Discharge}

Precipitation in 2007 totaled $1641 \mathrm{~mm}$ and was lower than the 1987-2007 mean of $1905 \mathrm{~mm}$. The greatest difference between measured and historical mean precipitation occurred in March 2007 when precipitation totaled $34 \mathrm{~mm}$ in contrast to the longterm monthly average of $250 \mathrm{~mm}$ (Figure 3). Total precipitation from February 2007 to January 2008 was $1829 \mathrm{~mm}$, of which roughly $476 \mathrm{~mm}$ occurred during times of sample collection. Precipitation and stream discharge were maximal from October to April. Annual average stream discharge was $17.9 \pm 3.6 \mathrm{~L} \mathrm{~s}^{-1}$ (Table 1). Stream discharge throughout the year was primarily dominated by base flow (Figure 3).

\section{Dissolved Organic Carbon}

Concentrations of DOC showed the highest seasonal variation in above-ground flow paths (e.g., rainfall, throughfall, stemflow, and overland flow). The concentration of DOC in rainfall was highest at the beginning of the rainy season, reaching a maximum of 15.6 $\pm 0.3 \mathrm{mg} \mathrm{C} \mathrm{L}^{-1}$ during the October 18, 2007 event, and declined throughout the rainy season, reaching a minimum of $3.3 \pm$ 


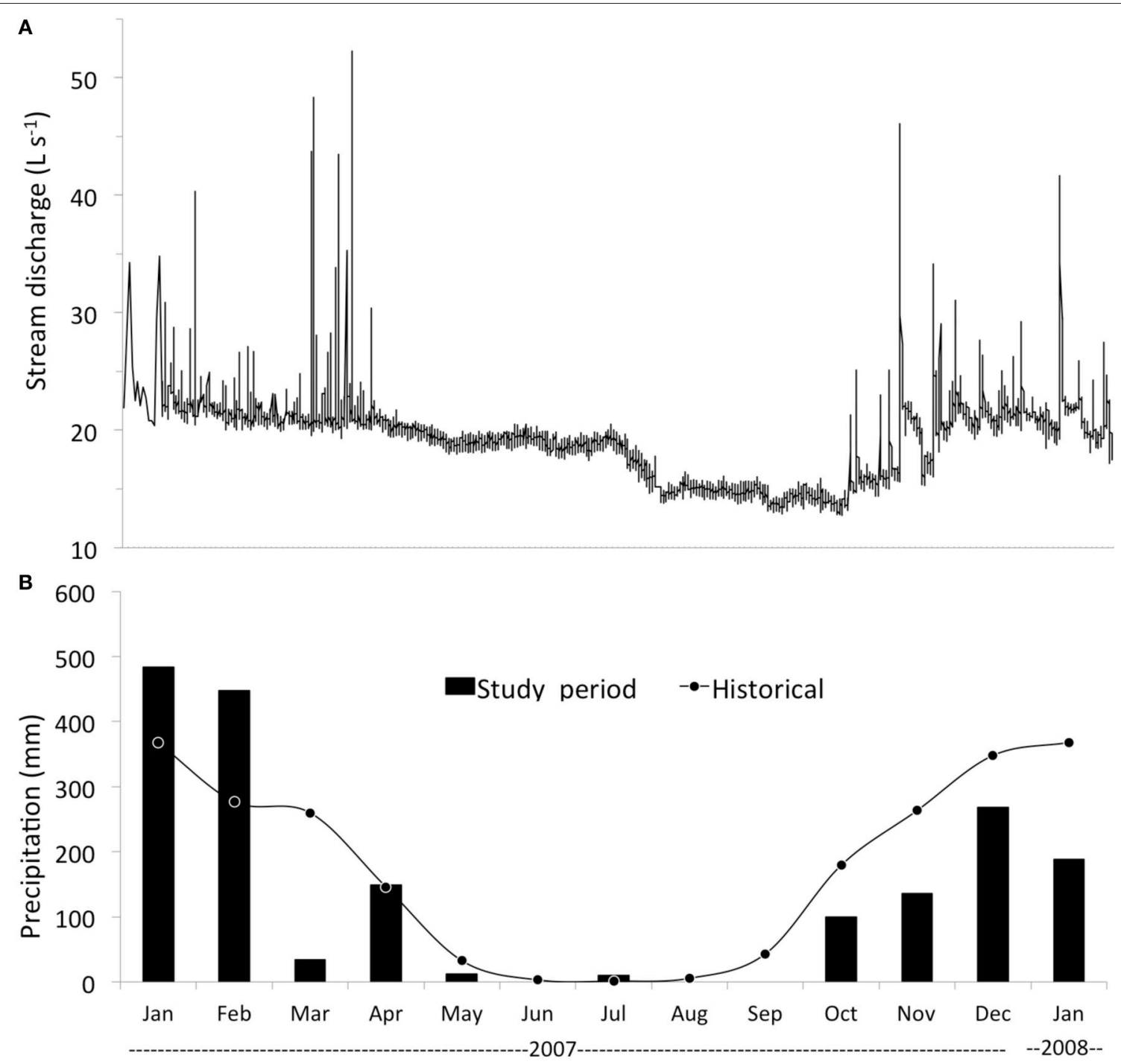

FIGURE 3 | Precipitation and discharge. Measurements of (A) Stream discharge and (B) historic average monthly precipitation (circles) and precipitation during the sampled rain events (bars) from January 2007 to January 2008.

$0.2 \mathrm{mg} \mathrm{C} \mathrm{L}^{-1}$ (Figure 4). The annual average DOC concentration in rainfall was $6.7 \pm 3.7 \mathrm{mg} \mathrm{C} \mathrm{L}^{-1}$ (Table 1). The concentration of DOC in throughfall was highest at the end of the dry season during the September 2007 rain event (126 $\left.\pm 68 \mathrm{mg} \mathrm{C} \mathrm{L}^{-1}\right)$, and declined throughout the rainy season. In April 2007, after a brief dry period the throughfall DOC concentrations increased from $35.7 \pm 20.0 \mathrm{mg} \mathrm{C} \mathrm{L}^{-1}$ during the March 2007 sampling to $77.5 \pm$ $28.7 \mathrm{mg} \mathrm{C} \mathrm{L}^{-1}$ (Figure 4). The annual average throughfall DOC concentration for lowland, hillside and plateau sub-parcels was $47.8 \pm 6.5,41.9 \pm 4.6$, and $42 \pm 4.4 \mathrm{mg} \mathrm{C} \mathrm{L}^{-1}$, respectively, showing minimal variation between the different topographic regimes $(\mathrm{p}=0.66)$.

Stemflow DOC concentrations varied both seasonally and as a function of tree diversity and the stem surface. In particular, stem rugosity and the presence or lack of epiphytes had a large influence on stemflow DOC in this study. The following species, characterized by a rugose bark and/or lichens on the stem, represent the majority of the trees sampled for stemflow and provided the greatest amount of DOC enrichment: Amaioua guianensis (bark with fissures and lichens), Trattinickia burseraefolia (bark with lichens), Hirtelar bicornis, Trattinickia glaziovii, Xylopia amazonica, Miconia punctate, Pseudolmedia murure, and Miconia pyrifolia (rugose bark and lichens on the stem). The following species, characterized by a smooth bark, were a minor fraction of the trees sampled and generally had low stemflow DOC concentrations: Licania egleri, Protium guianense, Protium unifoliolatum, Vochysia vismifolia, and Envira cana. As with rainfall DOC, stemflow DOC concentrations were highest at the beginning of the rainy season, reaching a maximum of $87.7 \pm$ $53 \mathrm{mg} \mathrm{C} \mathrm{L}^{-1}$ during the October 16, 2007 sampling, and steadily decreased throughout the rainy season (Figure 4). Annual average stemflow DOC concentrations in lowland, hillside and 
TABLE 1 | Average concentrations and annual fluxes of DOC, DIC, and water across the topographic gradient.

\begin{tabular}{|c|c|c|c|c|c|c|c|}
\hline Input/Flowpaths & & $\begin{array}{l}\text { DOC Concentration } \\
\left(\mathrm{mg} \mathrm{C} \mathrm{L}^{-1}\right)\end{array}$ & $\begin{array}{l}\text { DOC Flux Kg } \\
\mathrm{C} \mathrm{ha}^{-1} \mathrm{yr}^{-1}\end{array}$ & $\begin{array}{l}\text { DIC Concentration } \\
\left(\mathrm{mg} \mathrm{C} \mathrm{L}^{-1}\right)\end{array}$ & $\begin{array}{l}\text { DIC Flux Kg } \\
\mathrm{C} \mathrm{ha}^{-1} \mathrm{yr}^{-1}\end{array}$ & $\begin{array}{l}{ }^{\text {a Water flux }} \\
\text { (mm yr-1) }\end{array}$ & $\begin{array}{c}\text { Stream discharge } \\
\left(\mathrm{L} \mathrm{s}^{-1}\right)\end{array}$ \\
\hline Rainfall & & $6.7 \pm 3.7$ & $82.4 \pm 18.4$ & $0.8 \pm 0.7$ & $38.8 \pm 4.4$ & 1403.1 & - \\
\hline \multirow[t]{3}{*}{ bThroughfall } & Lowland & $47.8 \pm 6.5$ & $150.8 \pm 75.6$ & $2.5 \pm 2.3$ & $16.6 \pm 8.2$ & 1039.7 & - \\
\hline & Hillside & $41.9 \pm 4.6$ & & & & & \\
\hline & Plateau & $42.0 \pm 4.4$ & & & & & \\
\hline \multirow[t]{3}{*}{ Stemflow } & Lowland & $31.7 \pm 3.09$ & $1.5 \pm 0.8$ & $1.5 \pm 1.1$ & $0.6 \pm 0.1$ & 14 & - \\
\hline & Hillside & $32.5 \pm 3.34$ & & & & & \\
\hline & Plateau & $27.6 \pm 1.6$ & & & & & \\
\hline \multirow[t]{3}{*}{ Overlandflow } & Lowland & $57.2 \pm 10.6$ & $3.9 \pm 1.6$ & $1.3 \pm 1.3$ & $0.1 \pm 0.1$ & 7.3 & - \\
\hline & Hillside & $39.6 \pm 7.0$ & & & & & \\
\hline & Plateau & $40.9 \pm 5.7$ & & & & & \\
\hline \multirow[t]{3}{*}{ 'Soil Solution } & Lowland & $15.5 \pm 0.9$ & - & $7.7 \pm 1.3$ & - & - & - \\
\hline & Hillside & $16.0 \pm 1.4$ & - & $7.1 \pm 1.3$ & - & - & - \\
\hline & Plateau & $15.6 \pm 1.36$ & - & $6.7 \pm 1.3$ & - & - & - \\
\hline \multirow[t]{3}{*}{ Groundwater } & Lowland & $2.0 \pm 0.5$ & - & $2.7 \pm 0.3$ & - & - & - \\
\hline & Hillside & $1.4 \pm 0.3$ & - & $2.7 \pm 0.3$ & - & - & - \\
\hline & Plateau & $1.0 \pm 0.2$ & - & $3.7 \pm 0.4$ & - & - & - \\
\hline Stream & & $2.9 \pm 3.5$ & $1.7 \pm 0.2$ & $2.0 \pm 1.8$ & $0.9 \pm 0.2$ & - & $17.9 \pm 3.6$ \\
\hline
\end{tabular}

a Water fluxes measured during the sampling period from February 15, 2007 to January 25, 2008.

${ }^{b}$ Values represent the gross throughfall DOC/DIC contribution (e.g., the sum of rainfall and net throughfall).

${ }^{c}$ Values represent the average of 10,50,100, and $200 \mathrm{~cm}$ lysimeter depths.

plateau sub-parcels were $31.7 \pm 3.09,32.5 \pm 3.3$, and $27.6 \pm$ $1.6 \mathrm{mg} \mathrm{C} \mathrm{L}^{-1}$, respectively. Whereas lowland and hillside parcels had similar stemflow DOC concentrations, concentrations in plateau parcels were generally lower $(p<0.05)$.

Overland flow did not occur in events with low precipitation (e.g., March and April 2007 samplings, with 5 and $6 \mathrm{~mm}$ of precipitation, respectively). Lowland parcels had the highest overland flow volume compared to the oxisoils of the hillside and plateau parcels. Compared to the other above-ground flow paths, overland flow had the highest DOC concentrations. As with other above-ground flow paths, overland flow DOC concentrations were highest at the beginning of the rainy season, reaching a maximum of $160 \pm 110 \mathrm{mg} \mathrm{C} \mathrm{L}^{-1}$ during the October 16, 2007 sampling. Annual average overland flow DOC concentrations in lowland, hillside and plateau sub-parcels were $57.2 \pm 10.6,39.6$ \pm 7.0 , and $40.9 \pm 5.7 \mathrm{mg} \mathrm{C} \mathrm{L}^{-1}$, respectively. Concentrations did not vary significantly along the elevation gradient $(p=0.25)$. Although overland flow had the greatest DOC concentrations, this flow path represented a small fraction of the total water flow.

In contrast to the high DOC concentrations observed aboveground, below-ground DOC concentrations were generally lower. Soil solution DOC concentrations were highest at $10 \mathrm{~cm}$ depth, with an average of $17.7 \pm 2.0 \mathrm{mg} \mathrm{C} \mathrm{L}^{-1}$ and decreased to $11.9 \pm 1.0 \mathrm{mg} \mathrm{L}^{-1}, 16.4 \pm 1.5 \mathrm{mg} \mathrm{L}^{-1}$, and $14.9 \pm 1.3 \mathrm{mg} \mathrm{C} \mathrm{L}^{-1}$ at depths of 50,100, and $200 \mathrm{~cm}$ depths, respectively. Differences with depth were statistically significant $(p<0.05)$, whereas there was little variation along the topographic gradient $(p=0.33)$. It was not possible to extract soil solution samples during the long dry season and at the beginning of the rainy season with the methodology used here, however, as with the above-ground flow paths, soil solution DOC concentrations appeared to peak and decrease throughout the rainy season (Figure 4). The highest observed soil solution DOC concentrations occurred during the December 2007 event, with a value of $24.6 \pm 17 \mathrm{mg} \mathrm{C} \mathrm{L}^{-1}$. Litterfall typically accumulates and decomposes above ground during the dry season. Above ground flow paths transport DOC rich waters to the sub-surface, particularly during the first several periods of rainfall in a season.

Groundwater generally had the lowest concentration of DOC, and contrary to other flow paths, the highest values were observed during the dry season. The maximum groundwater DOC concentration was $4.9 \pm 4.0 \mathrm{mg} \mathrm{C} \mathrm{L}^{-1}$ during August 2007. Annual average concentrations of groundwater DOC in lowland, hillside, and plateau sub-parcels were $2.0 \pm 0.5,1.4 \pm 0.3$, and $1.0 \pm 0.2 \mathrm{mg} \mathrm{C} \mathrm{L}^{-1}$, respectively, with little variation across the topographic gradient (Table $1 ; p=0.19$ ). However, the lowlands had the highest carbon stock in the soil profile $\left(119 \mathrm{Mg} \mathrm{C} \mathrm{ha}^{-1}\right.$ at $140 \mathrm{~cm}$ depth) compared to hillside $\left(119 \mathrm{Mg} \mathrm{C} \mathrm{ha}^{-1}\right)$ and plateau $\left(105 \mathrm{Mg} \mathrm{C} \mathrm{ha}^{-1}\right.$ ) sub-parcels. Stream flow also had low DOC concentrations relative to the different flow paths, with an annual average concentration of $2.9 \pm 3.5 \mathrm{mg} \mathrm{C} \mathrm{L}^{-1}$ (Table 1). Stream DOC concentrations reached a maximum of $15.8 \pm 0.2 \mathrm{mg} \mathrm{L}^{-1}$ 


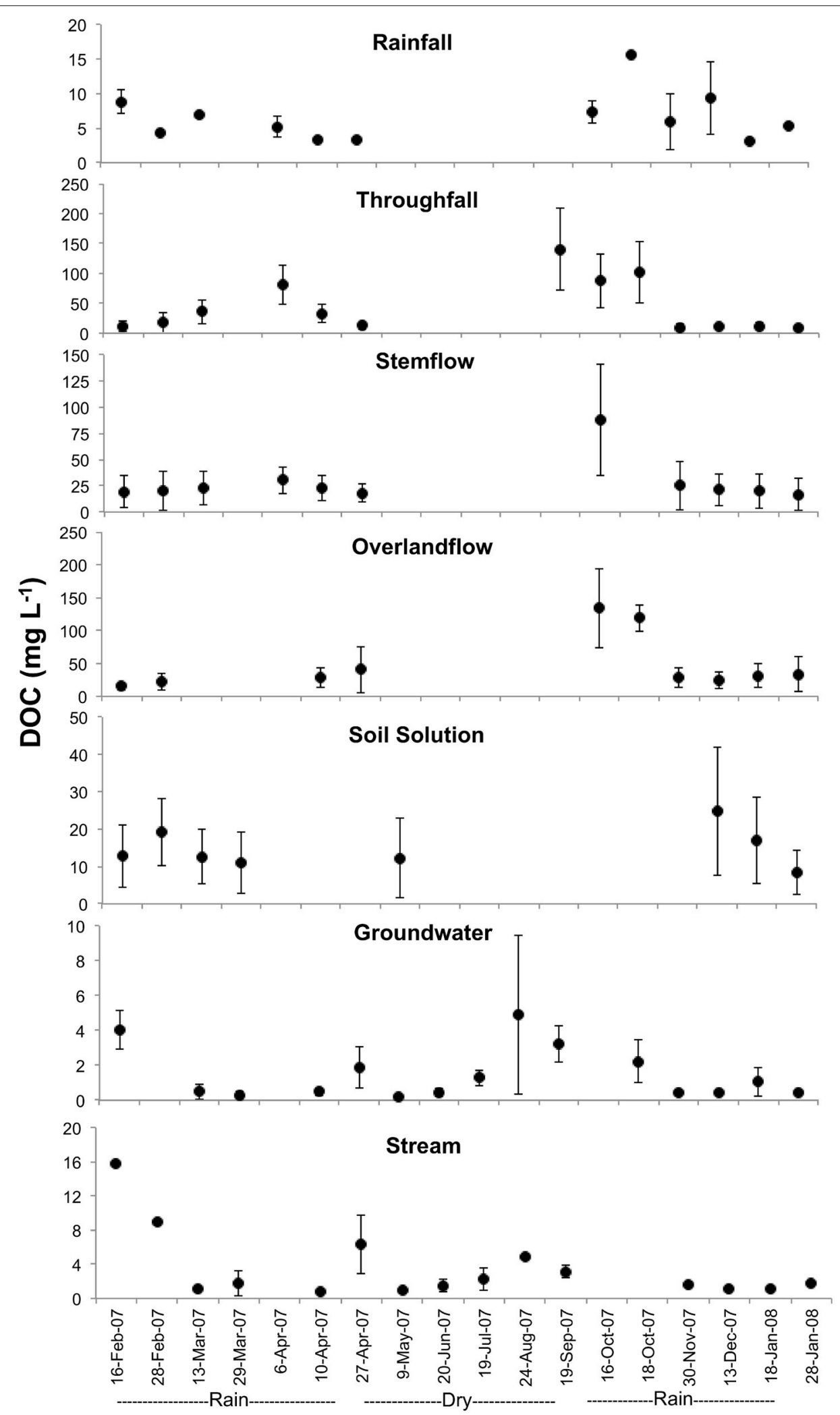

FIGURE 4 | Monthly DOC concentrations. Monthly measurements of the concentration of DOC in rainfall, throughfall, stemflow, overland flow, soil solution, groundwater, and stream water during rain events from February 2007 to January 2008. 
during the February 16, 2007 sampling when discharge was high, and decreased throughout the rainy season.

Based on the above measurements, the annual DOC flux in the watershed was estimated to be $82.4 \pm 18.4 \mathrm{~kg} \mathrm{C} \mathrm{ha}^{-1} \mathrm{yr}^{-1}$ for rainfall (Table 1). The gross flux of DOC for throughfall was $142.6 \pm 75.6 \mathrm{~kg} \mathrm{C} \mathrm{ha}^{-1} \mathrm{yr}^{-1}$, or $60.2 \pm 77.8 \mathrm{~kg} \mathrm{C} \mathrm{ha}^{-1} \mathrm{yr}^{-1}$ for net throughfall (i.e., the difference between gross throughfall and rainfall fluxes). DOC fluxes for stemflow, overland flow, and stream flow were $1.5 \pm 0.8,3.9 \pm 1.6$ and $1.7 \pm 0.2 \mathrm{~kg} \mathrm{C} \mathrm{ha}^{-1}$ $\mathrm{yr}^{-1}$, respectively (Table 1). It is important to note that the fluxes estimated for overland flow do not represent the actual flux to the stream, per se, since it is possible that the water collected with our methods could have potentially infiltrated less saturated soils further downslope before reaching the stream.

\section{Dissolved Inorganic Carbon}

Above-ground flow paths (e.g., rainfall, throughfall, stemflow, and overland flow) had relatively low DIC concentrations in contrast to the high DOC concentrations observed in these flow paths. The concentration of DIC in rainfall reached a maximum of $1.5 \mathrm{mg} \mathrm{C} \mathrm{L}^{-1}$ during the February 28, 2007 sampling (Figure 5), with an annual average of $0.8 \pm 0.7 \mathrm{mg} \mathrm{C}$ $\mathrm{L}^{-1}$ (Table 1). Throughfall DIC concentrations were generally highest near the end of the rainy season, with a maximum value of $4.5 \pm 2.4 \mathrm{mg} \mathrm{C} \mathrm{L}^{-1}$ during the April 6, 2007 sampling period. The annual average throughfall DIC concentration was $2.5 \pm 2.3 \mathrm{mg}$ $\mathrm{C} \mathrm{L}^{-1}$. Stemflow DIC concentrations increased at the beginning of the rainy period, reaching a maximum of $6.7 \pm 3.2 \mathrm{mg} \mathrm{C}$ $\mathrm{L}^{-1}$ during the October 16, 2007 sampling period. The annual average DIC concentration in stemflow was $1.5 \pm 1.1 \mathrm{mg} \mathrm{C} \mathrm{L}^{-1}$. Overland flow DIC concentrations reached a maximum of 2.4 $\pm 0.3 \mathrm{mg} \mathrm{C} \mathrm{L}^{-1}$ during the February 6, 2007 sampling period, and had annual average of $1.3 \pm 1.3 \mathrm{mg} \mathrm{C} \mathrm{L}^{-1}$ (Table 1). The concentration of DIC in each of these above-ground flow paths did not significantly vary between lowland, hillside and plateau sub-parcels.

In contrast to observations of above-ground flow paths, below-ground flow paths had relatively high DIC concentrations that were above atmospheric $\mathrm{CO}_{2}$ saturation levels. Soil solution DIC generally increased with soil depth, indicating $\mathrm{CO}_{2}$ accumulation along the profile. Soil solution DIC did not vary significantly among the different sites $(p=0.33)$. The annual average soil solution DIC concentration was $3.2 \pm 1.2 \mathrm{mg} \mathrm{C} \mathrm{L}^{-1}$ at $10 \mathrm{~cm}$ depth, $2.9 \pm 0.5 \mathrm{mg} \mathrm{C} \mathrm{L}^{-1}$ at $50 \mathrm{~cm}$ depth, $6.3 \pm 1.1 \mathrm{mg}$ $\mathrm{C} \mathrm{L}^{-1}$ at $100 \mathrm{~cm}$ depth, and $11.9 \pm 1.6 \mathrm{mg} \mathrm{C} \mathrm{L}^{-1}$ at $200 \mathrm{~cm}$ depth. Soil solution DIC concentrations were maximal during the February 16, 2007 sampling period with a value of $14.2 \pm 13.9 \mathrm{mg}$ $\mathrm{C} \mathrm{L}^{-1}$. In groundwater the annual average concentration of DIC in lowland, hillside and plateau sub-parcels was $2.7 \pm 0.3,2.7$ \pm 0.3 , and $3.7 \pm 0.4 \mathrm{mg} \mathrm{C} \mathrm{L}^{-1}$, respectively, differing along the topographic gradient, with the highest concentrations observed in plateau sub-parcels. Groundwater DIC concentrations reached

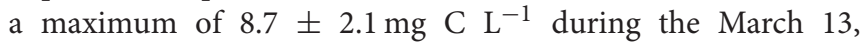
2007 sampling period (Figure 5). The annual average DIC concentration in stream flow was $1.6 \pm 1.0 \mathrm{mg} \mathrm{C} \mathrm{L}^{-1}$, with a maximum of $6.5 \mathrm{mg} \mathrm{L}^{-1}$ observed during the March 13, 2007 sampling period.
The annual flux of DIC through above-ground flow paths was significantly lower than DOC fluxes $(p<0.05)$. Based on the above measurements, the annual DIC flux in the watershed was estimated to be $38.8 \pm 4.4 \mathrm{~kg} \mathrm{C} \mathrm{ha}^{-1} \mathrm{yr}^{-1}$ for rainfall. The DIC flux for gross throughfall was $16.6 \pm 8.2 \mathrm{~kg} \mathrm{C} \mathrm{ha}^{-1} \mathrm{yr}^{-1}$ resulting in a net throughfall flux of $22.2 \pm 9.3 \mathrm{~kg} \mathrm{C} \mathrm{ha}^{-1} \mathrm{yr}^{-1}$. Stemflow, overland flow, and stream flow had DIC fluxes $0.6 \pm 0.1,0.1 \pm$ 0.1 , and $0.9 \pm 0.2 \mathrm{~kg} \mathrm{Cha}^{-1} \mathrm{yr}^{-1}$, respectively (Table 1).

\section{DISCUSSION}

\section{Dissolved Organic Carbon}

The concentration of DOC in rainfall was highest during the first large rainfall events after a long dry period and decreased throughout the wet season. This phenomenon is most likely a result of the accumulation of carbon-rich particulate material in the atmosphere during periods with minimal rainfall. This particulate material can be "washed" from the atmosphere during rainfall events (Greenfield, 1957) and a fraction of the particulate organic matter is solubilized into the dissolved phase in raindrops (Monteith et al., 2007). The atmospheric particulate material can be derived from a variety of natural and anthropogenic origins including aeolian transport, agricultural activities, and biomass burning (Ketseridis et al., 1976; Simoneit and Elias, 2000; Pio et al., 2001; Snyder et al., 2009). As with similar studies, our results indicate that the source of rainfall DOC that accumulates during dry periods is depleted during subsequent rainfall events, resulting in a decrease in rainfall DOC concentrations throughout the wet season (Filoso et al., 1999; Johnson et al., 2006a; Germer et al., 2007). Rainfall DOC fluxes in other regions studied in the Central Amazon were generally lower than our estimates. For example, rainfall fluxes in the Rio Negro region were roughly three times lower than the fluxes measured here (Table 2). Compared to the Xingu basin studied here, the Central Amazon generally experiences greater annual precipitation and is less impacted by deforestation and land use change (Andreae et al., 1990; Filoso et al., 1999; Waterloo et al., 2006). Rainfall DOC fluxes exceeding estimates made here were observed in other Amazonian regions that are highly influenced by biomass burning and land use alterations. For example a rainfall DOC flux of $106.5 \mathrm{~kg} \mathrm{ha}^{-1} \mathrm{yr}^{-1}$ was observed in Rondonia, Brazil, a site that is strongly affected by burning and land use alteration (Table 2; Artaxo et al., 2005; Germer et al., 2007).

As rainfall drains through the forest canopy, the throughfall becomes enhanced with DOC derived from leaf and plant surfaces, surficial decomposition processes, and animal excrement (Parker, 1983; Levia and Frost, 2003). Similar to rainfall, the enrichment of throughfall DOC was greatest during the first large rain events following a long dry period (Figure 4). Throughfall DOC concentrations dropped after subsequent rain events. Similar to the accumulation of carbon-rich particles in the atmosphere, organic carbon can accumulate on surfaces of the forest canopy during dry periods and be subsequently mobilized by throughfall during rain events. We not only observed enhanced throughfall DOC concentrations after a long dry season, but also after a month of dry weather from 


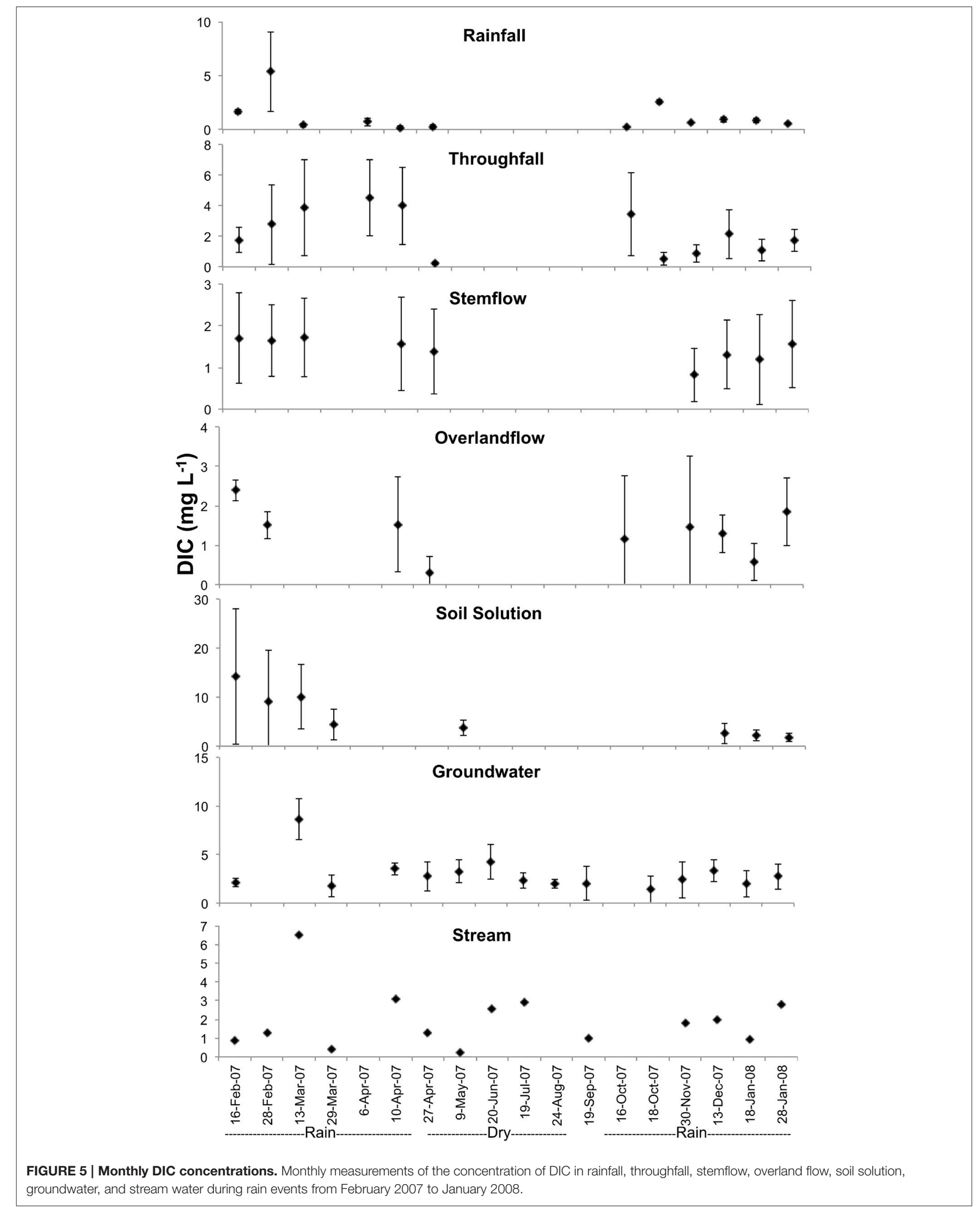


TABLE 2 | Annual DOC fluxes for rainfall, throughfall, net throughfall, stemflow, and overland flow in the Amazon basin.

\begin{tabular}{|c|c|c|c|c|c|c|c|}
\hline \multirow[t]{2}{*}{ Study Location } & \multicolumn{6}{|c|}{ Annual DOC flux $\left(\mathrm{kg} \mathrm{ha}^{-1} \mathrm{yr}^{-1}\right)$} & \multirow[t]{2}{*}{ References } \\
\hline & Rainfall & Throughfall & Net Throughfall & Stemflow & Overland Flow & Stream & \\
\hline Canarana, MT & 82.4 & 150.8 & 68.4 & 1.5 & 3.9 & 1.7 & This study \\
\hline Rondonia, RO & 106.4 & 301.6 & 195.1 & - & - & - & Germer et al., 2007 \\
\hline Juruena, MT & - & - & - & - & - & 31.5 & Johnson et al., 2006a \\
\hline Paragominas, PA & 123.4 & 149.0 & - & - & - & 4.1 & Markewitz et al., 2004 \\
\hline Rio Negro, AM & 27.5 & 190.0 & - & - & - & - & Filoso et al., 1999 \\
\hline
\end{tabular}

March to April 2007 (Figures 2, 3). These results illustrate the importance of atmospheric deposition and forest metabolism on throughfall organic carbon content. Rainfall DOC, on the other hand, was elevated during the March 2007 sampling, and once again depleted by the April 2007 samplings, illustrating that the accumulation and solubilization of atmospheric particulates with rainfall may, in some cases, occur more quickly than the accumulation of $\mathrm{OC}$ in the forest canopy and mobilization by throughfall. This is likely because throughfall DOC originates from a range of sources including atmospheric particles and surficial processes and characteristics. A similar magnitude of DOC in throughfall $\left(96.1 \pm 68.0 \mathrm{mg} \mathrm{C} \mathrm{L}^{-1}\right)$ was observed during the first rain after a long dry period in other Amazonian forests (Johnson et al., 2006a).

Stemflow and overland flow both had seasonal trends similar to throughfall (i.e., maximal DOC after the first rain event following a dry period). Stemflow generally represents a relatively minor flux of carbon. For example, here we measured an average DOC flux in stem flow of only $1.5 \pm 1.1 \mathrm{~kg} \mathrm{C} \mathrm{ha}^{-1} \mathrm{yr}^{-1}$, roughly an order of magnitude less than the throughflow and rainfall fluxes (Table 1; Figure 6). Stemflow is primarily controlled by tree diameter, bark rugosity, epiphyte presence, and the forest ground flora biodiversity (Dalva and Moore, 1991; Liu and Sheu, 2003; Wang et al., 2004; Johnson and Lehmann, 2006). For example, forests with extensive palm undergrowth generally have increased stemflow due to enhanced water collection and dispersal by the large palm leaves (Lloyd and Marques, 1988; Germer et al., 2007). In this study, stemflow was largely influenced by bark rugosity and the presence of epiphytes, with much higher stemflow DOC concentrations observed in trees with rugose bark and lichen coverage than trees with a smooth bark. Surface complexities such as these can allow enhanced accumulation of organic matter both from production and decomposition processes.

Lowland and hillside sub-parcels generally contained greater coverage of stem epiphytes and higher stemflow DOC concentrations than plateau sites. The lowland and hillside parcels were in close proximity to the stream, resulting in enhanced air humidity and epiphyte production, whereas plateau sites were more exposed to wind and further from the stream. Although stemflow DOC concentrations were higher in lowland and hillside parcels, the DOC flux was greatest in plateau sites, which had a larger proportion of trees with a diameter at breast height $>5 \mathrm{~cm}$ than lowland and hillside parcels (Table 1). The larger diameter trees provide a greater surface area for water to flow and organic carbon to solubilize (Dalva and Moore, 1991). Similar to our observations that stemflow represents a small DOC flux relative to total rainfall, other studies in the Amazon have shown that stemflow represents from roughly $2 \%$ (Lloyd and Marques, 1988) to 7-8\% (Jordan, 1978) of the total rainfall. Although the stemflow DOC concentrations measured here and elsewhere were relatively high, the volume of water comprising stem flow was low, resulting in a relatively small DOC flux (Dalva and Moore, 1991; Hinton et al., 1998).

Overland flow was generally low throughout the study period. The forest soils were characterized by high clay content and aggregate stability, allowing a high degree of infiltration (Brandão, 2006). There was no overland flow present during rain events with less than $6 \mathrm{~mm}$ of precipitation. Overland flow was generally highest in the lowland sub-parcels since the riparian zone was primarily composed of saturated gleysols. These soils are generally slow draining and sloped toward the stream channel (Deckers et al., 1998). The highest concentrations and fluxes of DOC in overland flow were observed in the lowland sites (Table 1), most likely because, relative to plateau and hillside sites, higher levels of soil saturation allow a greater volume of water to be in contact with litter layers. The overland DOC flux from plateau and hillside sites, on the other hand, was low relative to other flow paths due to the soil type and relief characteristics. Overland flow represents a rapid pathway for carbon transport, and often contains the highest concentration of DOC relative to other flowpaths in regions with highly saturated soils, however the overland DOC flux is generally low because overland flow represents a relatively small fraction of total water flow (Johnson et al., 2006a; Table 1). As with other above ground flow paths, overland flow DOC concentrations were highest during the first rainfall following a long dry period (Figure 4).

A large amount of the DOC that enters soils as throughfall/stemflow is removed as it travels through soils into streams (Qualls et al., 2002; Liu and Sheu, 2003). For example, in the temperate Appalachian mountains, roughly $95 \%$ of the DOC in throughfall was lost in soils prior to entering streams; roughly $10-33 \%$ of this DOC loss was attributed to biodegradation, while the remaining DOC was hypothesized to be removed by mineral sorption (Qualls and Haines, 1992). In this study, soil surface layers generally had high DOC concentrations, which decreased with soil depth. Groundwater had much lower DOC concentrations than the preceding flow paths during the rainy season, similar to other observations in the 


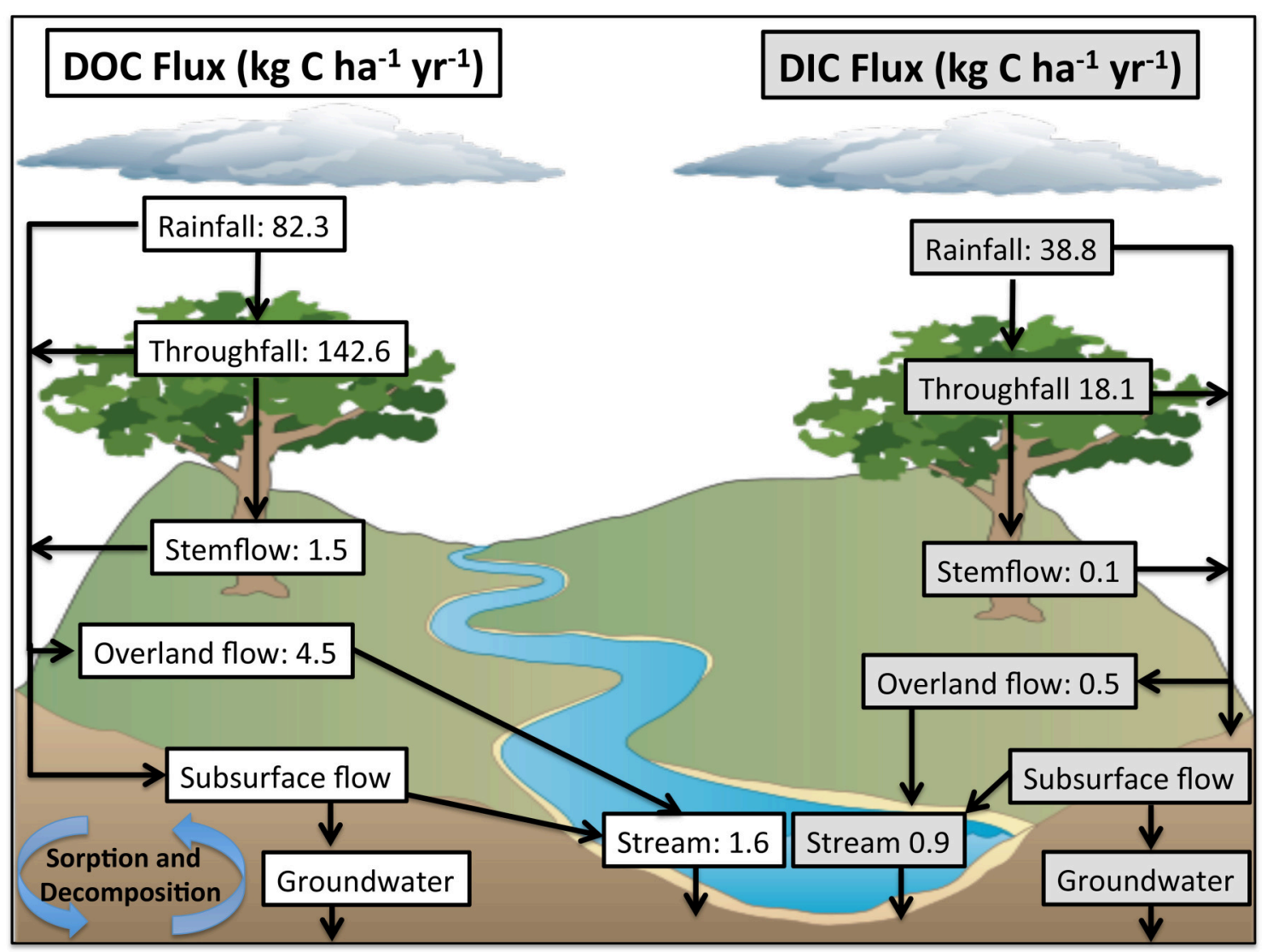

FIGURE 6 | Annual DOC and DIC fluxes. The average annual flux of DOC and DIC in rainfall, throughfall, stemflow, overland flow, and stream flow in the Tanguro Ranch watershed.

Amazon basin (Johnson et al., 2006a). Contrary to above-ground flow paths, groundwater DOC concentrations were highest during dry periods (Figure 4), indicating that groundwater DOC is primarily mobilized by baseflow and, perhaps, diluted by rapid rainfall. As rainfall percolates through subsoil layers, sorption of molecules onto iron and aluminum-rich mineral surfaces can remove a large fraction of the DOC. Sorption generally occurs rapidly relative to decomposition processes (McClain et al., 1997; Qualls et al., 2002; Liu and Sheu, 2003; Johnson et al., 2006a). Microbial degradation of OC in soils is another important pathway for DOC loss, and has potential to be enhanced by a warming climate (Feng et al., 2008). An emerging view is that the degree of OC decomposition in litterfall and soils is largely a component of environmental and biological conditions rather than intrinsic molecular properties (Schmidt et al., 2011).

Concentrations of DOC in the stream were a similar magnitude as in groundwater, on average, but increased during heavy rainfall after a dry period (e.g., February 2007). This is similar to other observations of DOC concentrations in temperate and tropical settings made during brief storm periods. For example, high frequency measurements have illustrated a strong correlation between stream discharge and DOC concentrations during rapid rain events (Boyer et al., 1997; Hinton et al., 1998; Buffam et al., 2001; Ward et al., 2012). These types of rapid loading events have been estimated to contribute to as much as $86 \%$ of annual OC export in temperate forested watersheds (Raymond and Saiers, 2010) and 71-85\% of OC export in temperate agricultural watersheds (Dalzell et al., 2007). Similar to our observations of accumulation and mobilization of DOC in above ground flow paths, others have observed a seasonal accumulation of OC in surface soil and litter layers, which is mobilized at the beginning of the wet season (Buffam et al., 2001; Raymond and Saiers, 2010; Ward et al., 2012). In addition to enhanced concentrations, it has been observed in both temperate and high-latitude river systems that OC biodegradability can increases with peak discharge during rain events (Buffam et al., 2001; Fellman et al., 2009). Although we observed enhanced DOC concentrations during periods of increasing discharge, rapid loading events were not as important with regards to annual stream DOC fluxes as in the cases described above because stream flow was largely dominated by baseflow (Figure 3). In our study site, stream flow was low relative to the amount of precipitation, likely as a result of high evapotranspiration rates (not measured here). As a result, the estimated stream DOC flux of $1.6 \mathrm{~kg}$ $\mathrm{C} \mathrm{ha} \mathrm{yr}^{-1}$ was considerably lower than in other Amazonian 
streams (Table 2). The flux of DOC in other Amazonian streams has been shown to be as high as $31.5 \mathrm{~kg} \mathrm{C} \mathrm{ha}^{-1} \mathrm{yr}^{-1}$ for white water streams and $190 \mathrm{~kg} \mathrm{C} \mathrm{ha}^{-1} \mathrm{yr}^{-1}$ for black water streams (Johnson et al., 2006a). Stream flow DOC fluxes are generally lower in subtropical forests, ranging from $4.1 \mathrm{~kg} \mathrm{C} \mathrm{ha}^{-1} \mathrm{yr}^{-1}$ (Qualls et al., 2002) to $25 \mathrm{~kg} \mathrm{C} \mathrm{ha}^{-1} \mathrm{yr}^{-1}$ (Liu and Sheu, 2003).

\section{Dissolved Inorganic Carbon}

Contrary to the relatively high levels of DOC in above ground compartments, the concentration of DIC was generally lowest in above-ground flow paths. Similar to other observations, above-ground DIC concentrations were generally near atmospheric $\mathrm{CO}_{2}$ saturation (Johnson et al., 2006b). The highest DIC concentrations were observed in the soil solution and groundwater. DIC concentrations generally increased throughout the rainy season for each respective flow path (Figure 5). In contrast to DOC concentrations, above-ground DIC concentrations progressively increased throughout the wet season (Figures 3, 4). The observed increase in soil solution DIC with precipitation is likely a result of enhanced biological decomposition and root respiration with increasing soil moisture. Soil solution DIC likely increased with soil depth since biological $\mathrm{CO}_{2}$ production is rapid relative to atmospheric gas exchange (Bekele et al., 2007). Plateau parcels had higher DIC concentrations at $200 \mathrm{~cm}$ depth $\left(3.7 \pm 0.4 \mathrm{mg} \mathrm{C} \mathrm{L}^{-1}\right)$ than hillside and lowland parcels $\left(2.7 \pm 0.3 \mathrm{mg} \mathrm{C} \mathrm{L}^{-1}\right)$ likely due to a combination of relatively thicker soil layers that inhibit gas exchange and less soil moisture in plateau parcels.

Root respiration and remineralization of organic matter to $\mathrm{CO}_{2}$ are the primary sources of DIC in soils and subsequent transport to groundwater reservoirs (Hope et al., 2004; Johnson et al., 2006b). Environmental conditions such as soil moisture/temperature, abiotic processes such as mineral sorption/desorption, and biological community composition/activity all influence rates of OC decomposition in soils (Schmidt et al., 2011). The fuels for OC remineralization range from simple substrates (e.g., carbohydrates) to molecularly complex compounds such as lignin macromolecules (Otto and Simpson, 2006; Feng et al., 2008; Kuzyakov, 2010; Thevenot et al., 2010). A similar range of organic carbon fuels are decomposed and remineralized to $\mathrm{CO}_{2}$ in streams and river channels (Benner et al., 1986, 1995; Mayorga et al., 2005; Ward et al., 2013). Photo-oxidative processes represent an additional pathway for remineralization of $\mathrm{OC}$ to $\mathrm{CO}_{2}$ in stream waters, and in some circumstances may enhance biological degradation rates (Hernes and Benner, 2003; Rodríguez-Zuniga et al., 2008; Spencer et al., 2009). Stream DIC concentrations were generally lower than in soil solution and groundwater because gas exchange occurs more rapidly in the aquatic environment (Hope et al., 2004; Johnson et al., 2006b).

\section{REFERENCES}

Andreae, M. O., Talbot, R. W., Berresheim, H., and Beecher, K. M. (1990). Precipitation chemistry in Central Amazonia. J. Geophys. Res. 95, 16987-16999. doi: 10.1029/JD095iD10p16987

\section{CONCLUDING REMARKS}

Understanding the magnitude and dynamics of carbon export in above and below ground flow paths is critical for constraining the influence of terrestrial and aquatic ecosystems on global carbon cycling. The evolution of carbon constituents along the continuum of terrestrial landscapes, inland waters, and ultimately the ocean is potentially largely dependent on initial interactions of raindrops with the surrounding environment. The results of this study illustrate the seasonality of carbon concentrations in above and below ground flow paths in tropical forests. Calculating a complete watershed carbon budget is logistically difficult, and, as such, flux estimates made here and elsewhere contain large uncertainties and methodological caveats that should be considered when making global comparisons. The flow paths examined here represent spatially-heterogeneous and rapid conduits, and as such, should be examined with increasingly high spatiotemporal resolution in order to fully unravel the complex underlying processes and inherent variability.

\section{AUTHOR CONTRIBUTIONS}

$\mathrm{VN}, \mathrm{AK}$, and $\mathrm{CN}$ conceived the experimental design and completed the field collections and sample processing. VN and NW interpreted the data and prepared the manuscript. All authors critically revised the manuscript and approved of the final submission.

\section{FUNDING}

This work was supported by FAPESP grant 03/13172-2, a FAPESP fellowship to VN and NSF Grant DEB 0640661 to CN.

\section{ACKNOWLEDGMENTS}

We thank Alexandra Montebelo and Gustavo Baldi for help with field sampling and laboratory analyses. We thank Dárlisson Nunes, Roberto Baena, Sandro, Ebes, Raimundo, and Artemizia Moitta of the Instituto de Pesquisa Ambiental na Amazonia (IPAM) for field help and IPAM and Daniel Nepstad for use of field facilities at Tanguro. Paul Lefebvre helped with watershed delineation, Shelby Hayhoe and Richard McHorney contributed stream discharge data. Access to Tanguro Rancho and rainfall data were provided by Grupo A. Maggi.

\section{SUPPLEMENTARY MATERIAL}

The Supplementary Material for this article can be found online at: http://journal.frontiersin.org/article/10.3389/fmars. 2016.00114 
Artaxo, P., Storms, H., Bruynseelsa, F., and Rieken, R. V. (1988). Composition and sources of aerosols from the Amazon Basin. J. Geophys. Res. 93, 1605-1615. doi: 10.1029/JD093iD02p01605

Aufdenkampe, A. K., Mayorga, E., Raymond, P. A., Melack, J. M., Doney, S. C., Alin, S. R., et al. (2011). Riverine coupling of biogeochemical cycles between, land, oceans, and atmosphere. Front. Ecol. Environ. 9, 53-60. doi: $10.1890 / 100014$

Bekele, A., Kellman, L., and Beltrami, H. (2007). Soil profile $\mathrm{CO}_{2}$ concentrations in forested and clear cut sites in Nova Scotia, Canada. Forest Ecol. Manag. 242, 587-597. doi: 10.1016/j.foreco.2007.01.088

Benner, R., Moran, M. A., and Hodson, R. E. (1986). Biogeochemical cycling of lignocellulosic carbon in marine and freshwater ecosystems: relative contributions of prokaryotes and eukaryotes. Limnol. Oceanogr. 31, 89-100. doi: 10.4319/lo.1986.31.1.0089

Benner, R., Opsahl, S., Chin-Leo, G., Richey, J. E., and Forsberg, B. (1995). Bacterial carbon metabolism in the Amazon River system. Limnol. Oceanogr. 40, 1262-1270. doi: 10.4319/lo.1995.40.7.1262

Boyer, E. W., Hornberger, G. M., Bencala, K. E., and McKnight, D. M. (1997). Response characteristics of DOC flushing in an alpine catchment. Hydrol. Process 11, 1635-1647.

Brandão, V. S. (2006). Infiltração da água no solo. Dissertation. Viçosa: Universidade Federal de Viçosa.

Buffam, I., Galloway, J. N., Blum, L. K., and McGlathery, K. J. (2001). A stormflow/baseflow comparison of dissolved organic matter concentrations and bioavailability in an Appalachian stream. Biogeochemistry 53, 269-306. doi: 10.1023/A:1010643432253

Dalva, M., and Moore, T. R. (1991). Sources and sinks of dissolved organic carbon in a forested swamp catchment. Biogeochemistry 15, 1-19. doi: $10.1007 /$ bf00002806

Dalzell, B. J., Filley, T. R., and Harbor, J. M. (2007). The role of hydrology in annual organic carbon loads and terrestrial organic matter export from a midwestern agricultural watershed. Geochim. Cosmochim. Acta 71, 1448-1462. doi: 10.1016/j.gca.2006.12.009

Deckers, J. A., Nachtergaele, F., and Spaargaren, O. C. (1998). World Reference Base for Soil Resources. Leuven: Acco.

Hope, D., Palmer, S. M., Billett, M. F., and Dawson, J. J. C. (2004). Variations in dissolved $\mathrm{CO}_{2}$ and $\mathrm{CH}_{4}$ in a first-order stream and catchment: an investigation of soil-stream linkages. Hydrol. Process 18, 3255-3275. doi: 10.1002/ hyp. 5657

Fellman, J. B., Hood, E., Edwards, R. T., and D’Amore, D. V. (2009). Changes in the concentration, biodegradability, and fluorescent properties of dissolved organic matter during stormflows in coastal temperate watersheds. J. Geophys. Res. Biogeosci. 114, G1. doi: 10.1029/2008JG000790

Feng, X. J., Simpson, A. J., Wilson, K. P., Williams, D. D., and Simpson, M. J. (2008). Increased cuticular carbon sequestration and lignin oxidation in response to soil warming. Nature Geosci. 1, 836-839. doi: 10.1038/ ngeo361

Ferreira, S. J. F., Luizão, F. J., and Dallarosa, R. L. G. (2005). Precipitação interna e interceptação da chuva em floresta de terra firme submetida à extração seletiva de madeira na Amazônia Central. Acta Amazonica 35, 55-62. doi: 10.1590/S0044-59672005000100009

Field, C., Behrenfeld, M., Randerson, J., and Falkowski, P. (1998). Primary production of the biosphere: integrating terrestrial and oceanic components. Science 281, 237-240. doi: 10.1126/science.281.5374.237

Filoso, S., Williams, M. R., and Melack, J. M. (1999). Composition and deposition of throughfall in a flooded forest archipelago. Biogeochemistry 45, 169-195. doi: 10.1007/BF01106780

Germer, S., Neill, C., Krusche, A. V., Gouveia Neto, S. C., and Elsenbeer, H. (2007). Seasonal and within-event dynamics of rainfall and throughfall chemistry in an open tropical rainforest in Rondônia, Brazil. Biogeochemistry 86, 155-174. doi: 10.1007/s10533-007-9152-9

Greenfield, S. M. (1957). Rain scavenging of radioactive particulate matter from the atmosphere. J. Meteorol. 14, 115-125. doi: 10.1175/1520-0469(1957)014<0115: RSORPM $>2.0 . \mathrm{CO} ; 2$

Hernes, P. J., and Benner, R. (2003). Photochemical and microbial degradation of dissolved lignin phenols: implications for the fate of terrigenous dissolved organic matter in marine environments. J. Geophys. Res. Oceans. 108, C9. doi: 10.1029/2002JC001421
Hinton, M. J., Schiff, S. L., and English, M. C. (1998). Sources and flowpaths of dissolved organic carbon during storms in two forested watersheds of the Precambrian Shield. Biogeochemistry 41, 175-197.

Horton, R. B. (1933). The role of infiltration in the hydrologic cycle. Eos Trans. Am. Geophys. Union. 14, 446-460. doi: 10.1029/TR014i001p00446

Ivanauskas, N. M., Monteiro, R., and Rodrigues, R. R. (2004). Estrutura de um trecho de floresta Amazônica na bacia do alto rio Xingu. Acta Amazonica 34, 275-299. doi: 10.1590/S0044-59672004000200015

Johnson, M. S., and Lehmann, J. (2006). Double-funneling of trees: stemflow and root-induced preferential flow. Ecoscience 13, 324-333. doi: 10.2980/i11956860-13-3-324.1

Johnson, M. S., Lehmann, J., Couto, E. G., Novães Filho, J. P., and Riha, S. J. (2006b). DOC and DIC in flowpaths of Amazonian headwater catchments with hydrologically contrasting soils. Biogeochemistry 81, 45-57. doi: 10.1007/s10533-006-9029-3

Johnson, M. S., Lehmann, J., Selva, E. C., Abdo, M., Riha, S., and Couto, E. G. (2006a). Organic carbon fluxes within and streamwater exports from headwater catchments in the southern Amazon. Hydrol. Process 20, 2599-2614. doi: 10.1002/hyp.6218

Jordan, C. F. (1978). Stem flow and nutrient transfer in a tropical rain Forest. Oikos 31, 257-263. doi: 10.2307/3543571

Ketseridis, G., Hahn, J., Jaenicke, R., and Junge, C. (1976). The organic constituents of atmospheric particulate matter. Atmos. Environ. 10, 603-610. doi: 10.1016/ 0004-6981(76)90045-7

Kuzyakov, Y. (2010). Priming effects: interactions between living and dead organic matter. Soil Biol. Biochem. 42, 1363-1371. doi: 10.1016/j.soilbio.2010.04.003

Levia, D. F., and Frost, E. E. (2003). A review and evaluation of stemflow literature in the hydrologic and biogeochemical cycles of forested and agricultural ecosystems. J. Hydrol. 274, 1-29. doi: 10.1016/S0022-1694(02)00399-2

Likens, G. E., and Eaton, J. S. (1970). A polyurethane stemflow collector for trees and shrubs. Ecology 51, 938-939. doi: 10.2307/1933996

Linsley, R. K. Jr., Kohler, M. A., and Paulhus, J. L. H. (1975). Hydrology for Engineers. New York, NY: McGraw-Hill Book Co.

Liu, C. P., and Sheu, B. H. (2003). Dissolved organic carbon in precipitation, throughfall, stemflow, soil solution, and stream water at the Guandaushi subtropical forest in Taiwan. Forest Ecol. Manag. 172, 315-325. doi: 10.1016/S0378-1127(01)00793-9

Lloyd, C. R., and Marques, A. D. (1988). Spatial variability of throughfall and stemflow measurements in Amazonian rainforest. Agric. For. Meteorol. 42, 63-73. doi: 10.1016/0168-1923(88)90067-6

Malhi, Y., Roberts, J. T., Betts, R. A., Killeen, T. J., Li, W., and Nobre, C. A. (2008). Climate change, deforestation, and the fate of the Amazon. Science 319, 169-172. doi: 10.1126/science.1146961

Markewitz, D., Eric Davidson, E., Moutinho, P., and Nepstad, D. (2004). Nutrient loss and redistribution after forest clearing on highly weathered soil in Amazonia. Ecol. Appl. 14, 177-199. doi: 10.1890/01-6016

Mayorga, E., Aufdenkampe, A. K., Masiello, C. A., Krusche, A. V., Hedges, J. I., Quay, P. D., et al. (2005). Young organic matter as a source of carbon dioxide outgassing from Amazonian rivers. Nature 436, 538-541. doi: 10.1038 /nature03880

McClain, M., Richey, J. E., Brandes, J., and Pimentel, T. (1997). Dissolved organic matter and terrestrial-lotic linkages in the central Amazon basin of Brazil. Global Biogeochem. Cycles 11, 295-311. doi: 10.1029/97GB01056

Monteith, D. T., Stoddard, J. L., Evans, C. D., de Wit, H. A., Forsius, M., Høgåsen, T., et al. (2007). Dissolved organic carbon trends resulting from changes in atmospheric deposition chemistry. Nature 450, 537-540. doi: 10.1038/ nature 06316

Neu, V., Neill, C., and Krusche, A. V. (2011). Gaseous and fluvial carbon export from an Amazon forest watershed. Biogeochemistry 105, 133-147. doi: 10.1007/s10533-011-9581-3

Otto, A., and Simpson, M. J. (2006). Evaluation of $\mathrm{CuO}$ oxidation parameters for determining the source and stage of lignin degradation in soil. Biogeochemistry 80, 121-142. doi: 10.1007/s10533-006-9014-x

Parker, G. G. (1983). Throughfall and stemflow in the forest nutrient cycle. $A d v$. Ecol. Res. 13, 57-133. doi: 10.1016/S0065-2504(08)60108-7

Pio, C. A., Alves, C. A., and Duarte, A. C. (2001). Identification, abundance and origin of atmospheric organic particulate matter in a Portuguese rural area. Atmos. Environ. 35, 1365-1375. doi: 10.1016/S1352-2310(00)00391-5 
Qualls, R. G., and Haines, B. L. (1992). Biodegradability of dissolved organic matter in forest throughfall, soil solution, and stream water. Soil Sci. Am. J. 56, 578-586. doi: 10.2136/sssaj1992.03615995005600020038x

Qualls, R. G., Haines, B. L., Swank, W. T., and Tyler, S. W. (2002). Retention of soluble organic nutrients by a forested ecosystem. Biogeochemistry 61, 135-171. doi: 10.1023/A:1020239112586

Radambrasil (1981). Folha SD. 22 Goiás: geologia, geomorfologia, pedologia, vegetação, uso potencial da terra. Rio de Janeiro: DNPM 636, 27-234.

Raymond, P. A., Caraco, N. F., and Cole, J. J. (1997). Carbon dioxide concentration and atmospheric flux in the Hudson River. Estuaries 20, 381-390. doi: $10.2307 / 1352351$

Raymond, P. A., Hartmann, J., Lauerwald, R., Sobek, S., McDonald, C., Hoover, M., et al. (2013). Global carbon dioxide emissions from inland waters. Nature 503, 355-359. doi: 10.1038/nature 12760

Raymond, P. A., and Saiers, J. E. (2010). Event controlled DOC export from forested watersheds. Biogeochemistry 100, 197-209. doi: 10.1007/s10533-0109416-7

Richey, J. E., Melack, J. M., Aufdenkampe, A. K., Ballester, V. M., and Hess, L. L. (2002). Outgassing from Amazonian rivers and wetlands as a large tropical source of atmospheric $\mathrm{CO}_{2}$. Nature 416, 617-620. doi: 10.1038/416617a

Rodríguez-Zuniga, U. F., Milori, D. M. B. P., Da Silva, W. T. L., Martin-Neto, L., Oliveira, L. C., and Rocha, J. C. (2008). Changes in optical properties caused by ultraviolet-irradiation of aquatic humic substances from the Amazon River Basin: seasonal variability evaluation. Environ. Sci. Technol. 42, 1948-1953. doi: 10.1021/es702156n

Schmidt, M. W., Torn, M. S., Abiven, S., Dittmar, T., Guggenberger, G., Janssens, I. A., et al. (2011). Persistence of soil organic matter as an ecosystem property. Nature 478, 49-56. doi: 10.1038/nature10386

Simoneit, B. R., and Elias, V. O. (2000). Organic tracers from biomass burning in atmospheric particulate matter over the ocean. Mar. Chem. 69, 301-312. doi: 10.1016/S0304-4203(00)00008-6

Snyder, D. C., Rutter, A. P., Collins, R., Worley, C., and Schauer, J. J. (2009). Insights into the origin of water soluble organic carbon in atmospheric fine particulate matter. Aerosol Sci. Technol. 43, 1099-1107. doi: 10.1080/02786820 903188701

Spencer, R. G. M., Stubbins, A., Hernes, P. J., Baker, A., Mopper, K., Aufdenkampe, A. K., et al. (2009). Photochemical degradation of dissolved organic matter and dissolved lignin phenols from the Congo River. J. Geophys. Res. 114, G3. doi: 10.1029/2009JG000968

Talbot, R. W., Andreae, M. O., Berresheim, H., Artaxo, P., Garstang, M., Harriss, R. C., et al. (1990). Aerosol chemistry during the wet season in central Amazonia: the influence of long-range transport. J. Geophys. Res. 95, 955-969.

Thevenot, M., Dignac, M. F., and Rumpel, C. (2010). Fate of lignins in soils: a review. Soil Biol. Biochem. 42, 1200-1211. doi: 10.1016/j.soilbio.2010.03.017

Vianello, R. L., and Alves, A. R. (2002). Meteorologia Básica e Aplicações. (Viçosa: UFV), 449.

Walter, H. (1979). Vegetation of the Earth and Ecological Systems of the Geobiosphere. New York, NY: Springer, 19-106.

Wang, M. C., Liu, C. P., and Sheu, B. H. (2004). Characterization of organic matter in rainfall, throughfall, stemflow, and streamwater from three subtropical forest ecosystems. J. Hydrol. 289, 275-285. doi: 10.1016/j.jhydrol.2003.11.026

Ward, N. D., Keil, R. G., Medeiros, P. M., Brito, D. C., Cunha, A. C., Dittmar, T., et al. (2013). Degradation of terrestrially derived macromolecules in the Amazon River. Nat. Geosci. 6, 530-533. doi: 10.1038/ngeo1817

Ward, N. D., Richey, J. E., and Keil, R. G. (2012). Temporal variation in river nutrient and dissolved lignin phenol concentrations and the impact of storm events on nutrient loading to Hood Canal, WA, USA. Biogeochemistry 111, 629-645. doi: 10.1007/s10533-012-9700-9

Waterloo, M. J., Oliveira, S. M., Drucker, D. P., Nobre, A. D., Cuartas, L. A., Hodnett, M. G., et al. (2006). Export of organic carbon in run-off from an amazonian rainforest blackwater catchment. Hydrol. Process 20, 2581-259. doi: 10.1002/hyp.6217

Conflict of Interest Statement: The authors declare that the research was conducted in the absence of any commercial or financial relationships that could be construed as a potential conflict of interest.

Copyright (c) $2016 \mathrm{Neu}$, Ward, Krusche and Neill. This is an open-access article distributed under the terms of the Creative Commons Attribution License (CC BY). The use, distribution or reproduction in other forums is permitted, provided the original author(s) or licensor are credited and that the original publication in this journal is cited, in accordance with accepted academic practice. No use, distribution or reproduction is permitted which does not comply with these terms. 